\title{
Penggunaan Model Pembelajaran Modelling The Way dapat Meningkatkan Hasil Belajar Solat pada Siswa Sekolah Dasar
}

\section{Zidni Nurhayati}

SDN 3 Belikurip

zidninur1971@gmail.com

\author{
Article History \\ accepted 01/02/2020
}

\begin{abstract}
The study is intended to determine the use of the model of learning modeling the way to improve prayer learning outcomes. Research is a research kuantitatif, by taking the data second grade students in an elementary school in the district Baturetno Wonogiri for less over 6 monts are in January up up to June 2019. Subjects carrying out the action were subject matter teachers in Islamic Religious Education while the subjects subjected to the action were grade II students totaling 11 students. The implementation of this research was divided into 2 cycles while the data collection methods used were documentation, observation, interviews and tests. The analysis and data techniques in the study were carried out in a qualitative descriptive manner carried out through the flow. The results showed an increase in prayer learning outcomes after using the way modeling learning model in class II students in an elementary school in Baturetno Wonogiri District, the value of learning outcomes with the KKM 75 provision obtained test results from pre-cycle conditions to Cycle I then to Cycle II had increased by 18 ie from the class average value of learning outcomes 67 with a predicate less value in the initial condition rose to an average of 76 with a predicate of sufficient value in Cycle I then rose to an average of 85 with a predicate of good grades in Cycle II. Increased student completeness with 11 students by $63.6 \%$, from 4 students or $36.4 \%$ of students completed in the initial condition to 7 students or $63.6 \%$ of students completed in Cycle I and became 11 students or $100 \%$ of students completed in the Cycle II. Based on these results it can be concluded that the use of the way modeling learning model can improve prayer learning outcomes in elementary school students.
\end{abstract}

Keywords: modeling the way, results learning, solat

\section{Abstrak}

Penelitian ini bertujuan untuk mengetahui penggunaan model pembelajaran modeling the way untuk meningkatkan hasil belajar solat. Penelitian ini merupakan penelitian kuantitatif, dengan mengambil data siswa kelas II di suatu Sekolah Dasar di Kecamatan Baturetno Wonogiri selama kurang lebih 6 bulan yaitu bulan Januari sampai dengan Juni 2019. Subjek yang melaksanakan tindakan adalah guru mapel Pendidikan Agama Islam sedangkan Subjek yang dikenai tindakan adalah siswa kelas II yang berjumlah 11 siswa. Pelaksanaan penelitian ini dibagi menjadi 2 siklus sedangkan metode pengumpulan data yang digunakan adalah dokumentasi, observasi, wawancara dan tes. Teknik analisis dan data pada penelitian dilakukan secara diskriptif kualitatif dilaksanakan melalui alur. Hasil penelitian menunjukkan terdapat peningkatan hasil belajar solat setelah digunakan model pembelajaran modeling the way pada siswa kelas II di suatu Sekolah Dasar di Kecamatan Baturetno Wonogiri, nilai hasil belajar dengan ketentuan KKM 75 diperoleh hasil tes dari kondisi prasiklus ke Siklus I kemudian ke Siklus II mengalami kenaikan sebesar 18 yaitu dari rata-rata kelas nilai hasil belajar 67 dengan predikat nilai kurang pada kondisi awal naik menjadi rata-rata 76 dengan predikat nilai cukup di Siklus I kemudian naik menjadi rata-rata 85 dengan predikat nilai baik di Siklus II. Peningkatan ketuntasan siswa dengan jumlah siswa 11 sebesar $63,6 \%$ yaitu dari 4 siswa atau $36,4 \%$ siswa tuntas pada kondisi awal menjadi 7 siswa atau $63,6 \%$ siswa tuntas pada Siklus I dan menjadi 11 siswa atau $100 \%$ siswa tuntas pada Siklus II. Berdasarkan hasil penelitian 
Volume 8 Nomor 1 Tahun 2020

tersebut dapat disimpulkan bahwa penggunaan model pembelajaran modeling the way dapat meningkatkan hasil belajar solat pada siswa Sekolah Dasar.

Kata kunci: model the way, hasil belajar, solat 


\section{PENDAHULUAN}

Keberhasilan pendidikan yang berkualitas sangat diharapkan oleh kita semua terutama kita sebagai orang pendidikan. Untuk mewujudkan keberhasilan pendidikan berkualitas dibutuhkan andil dari semua pihak. Keberhasilan pendidikan berkualitas dimulai dari keberhasilan pembelajaran di kelas. Keberhasilan pembelajaran tidak mungkin dapat terwujud begitu saja tanpa ada usaha perbaikan atau pembenahan diberbagai faktor. Faktor-faktor yang mempengaruhi belajar tersebut guru dan cara mengajarnya merupakan salah satu faktor yang juga sangat mempengaruhi keberhasilan belajar seseorang. Untuk itu sebagai guru hendaknya menguasai berbagai model pembelajaran, metode atau cara mengajar yang baik dalam pembelajarannya. Guru harus selalu mengikuti perkembangan zaman, menggunakan model pembelajaran, metode atau model pembelajaran yang aktif, inovatif dan kreatif. Ada berbagai macam model pembelajaran aktif. Salah satunya yaitu penggunaan model pembelajaran modeling the way untuk mengajarkan materi PAl khususnya kompetensi dasar mempraktikkan solat dengan tertib, diharapkan dapat meningkatkan keberhasilan pembelajaran khususnya solat, karena pembelajaran solat tersebut sangat penting. Solat merupakan dasar pokok yang harus dikuasai siswa kelas rendah sebelum mempelajari ketrampilan praktek selanjutnya seperti mengaji, azan dan lain sebagainya. Diharapkan dengan penerapan model pembelajaran modeling the way tersebut siswa akan lebih bersemangat, antusias dan konsentrasi dalam mengikuti pembelajaran solat dengan melihat langsung contoh praktek atau demonstrasi solat dari guru maupun temannya.

Pembelajara khususnya dalam kompetensi dasar mempratikkan solat dengan tertib sebetulnya guru sudah menerapkan penggunaan model pembelajaran, tetapi belum terlihat hasilnya. Hal itu berdampak pada tingkat penguasaan materi solat pada siswa rendah. Jika masalah ini tidak segera diatasi, maka berdampak pada ketidakberhasilan/ kegagalan dari Pendidikan Agama Islam di tingkat Sekolah Dasar, karena solat merupakan dasar pokok yang harus dikuasai siswa kelas rendah sebelum mempelajari ketrampilan praktek selanjutnya seperti mengaji, azan dan lain sebagainya. Berbagai resiko yang akan muncul diantaranya: Siswa akan semakin malas dalam mengikuti pembelajaran solat dengan baik dan benar, Siswa semakin takut, menjauhi dan malas belajar solat, Guru tidak mengetahui kesulitan yang dihadapi siswa dalam belajar solat dengan baik dan benar.

Memperhatikan dari asumsi dan realita di atas, maka sebagai upaya guru untuk meningkatkan penguasaan materi solat tersebut yaitu akan menerapkan model pembelajaran modeling the way. Penelitian yang berkaitan dengan pembelajaran dan model pembelajaran telah banyak dilakukan oleh peneliti sebelumnya, seperti yang telah dilakukan oleh Mahasiswa UIN Walisongo Semarang Fakultas Tarbiyah dan Keguruan, Program Studi PGMI, NIM : 123911152, atas nama : Siti Mufadlilah dengan judul "Upaya Meningkatkan Hasil Belajar Siswa Menggunakan Strategi Modeling The Way Pada Pembelajaran Fiqih Materi Azan dan Iqamah di Kelas II MI Tarbiyatul Islam Genuk Semarang Semester II Tahun Pelajaran 2015/2016", ternyata dengan penelitian tersebut dapat meningkatkan hasil belajar selain itu juga penelitian yang dilakukan oleh Mahasiswa Fakultas tarbiyah dan Keguruan Universitas Islam Negeri Sultan Syarif Kasim Riau Pekan Baru, NIM : 10811004857, atas nama : Elmiati dengan judul "Penerapan Strategi Modeling The Way Untuk Meningkatkan Kemampuan Melafazkan Hukum Qawli Shalat Fardhu Pada Siswa sekolah Menengah Pertama Rusqah Pekan Baru", dalam penelitian ini juga dapat meningkatkan kemampuan siswa.

Berdasarkan kedua penelitian tersebut dapat disimpulkan bahwa dengan menggunakan model pembelajaran modeling the way dapat meningkatkan hasil belajar siswa. Harapan yang ingin dicapai oleh peneliti dalam menggunakan model pembelajaran modeling the way ini adalah untuk meningkatkan hasil belajar siswa dan kreativitas guru sehingga tujuan dalam pembelajaran dapat tercapai. 
Model pembelajaran modelling the waymerupakan salah satu model pembelajaran yang memberikan kesempatan kepada peseta didik untuk dapat memaparkan apa yang telah diketahuinya di depan kelas secara langsung kepada siswa lain. Model pembelajaran ini sangat memberikan pengaruh yang berarti bagi peserta didik sehingga mereka berani mengemukakan pendapat dan ilmu yang dimiliki dalam forum yang lebih luas. Metode Modeling The Way merupakan salah satu metode mengajar yang dikembangkan oleh Mel Silbermam, seorang yang memang berkompeten dibidang psikologi pendidikan. Metode ini merupakan sekumpulan dari 101 strategi pengajaran. Sebuah metode yang menitik beratkan pada kemampuan seorang siswa untuk mengembangkan potensi yang ada dalam dirinya. Karena siswa dituntut untuk bermain peran sesuai dengan materi yang diajarkan.

Pendapat ahli menyatakan bahwa Model Pembelajaran modelling the way adalah model pembelajaran yang memberikan kesempatan kepada peserta didik untuk mempraktikan keterampilan spesifik yang dipelajari di kelas untuk demonstrasi. Dapat dipahami bahwa model pembelajaran modelling the way merupakan salah satu model pembelajaran yang membimbing siswa untuk mampu memaparkan apa yang telah dipelajarinya di kelas dalam bentuk demonstrasi atau praktik langsung di depan siswa lainnya. Selain itu, di dalam pembelajaran peserta didik diberi waktu untuk menciptakan skenario sendiri, membaca dan menentukan bagaimana mereka mengilustrasikan keterampilan dan teknik yang baru saja dijelaskan. Model ini sangat baik jika digunakan untuk mengajarkan pelajaran yang menuntut keterampilan tertentu.

Pendapat lain menyatakan Strategi pembelajaran modeling the way merupakan strategi pembelajaran yang memberi kesempatan kepada siswa untuk mempraktikkan keterampilan spesifik yang dipelajari di kelas melalui demonstrasi. Siswa diberi waktu untuk menciptakan skenario sendiri dan menentukan bagaimana mereka mengilustrasikan keterampilan dan teknik yang baru saja dijelaskan. Model pembelajaran ini akan sangat baik jika digunakan untuk mengajarkan pelajaran yang menuntut keterampilan tertentu. Dapat dipahami bahwa model pembelajaran modeling the waymerupakan model pembelajaran yang menuntut siswa untuk dapat mempraktikkan apa yang telah dipelajarinya di depan kelas. Siswa memiliki kesempatan untuk menyusun sendiri dan dalam bentuk apa yang ingin disampaikannya.

Model pembelajaran Modeling The Way adalah suatu model pembelajaran yang dilaksanakan dengan cara guru memberikan skenario suatu sub bahasan untuk didemonstrasikan siswa di depan kelas, sehingga menghasilkan ketangkasan dengan keterampilan atau skill dan profesionalisme. Ada sebuah pendapat lain menyatakan bahwa model pembelajaran Modeling The Way merupakan metamorfosa dari metode sosiodrama. Yakni sebuah metode dengan cara mendramatisasikan suatu tindakan atau tingkah laku dalam hubungan sosial. Dengan kata lain guru memberikan kesempatan kepada siswa untuk melakukan kegiatan atau peran tertentu sebagaimana yang ada dalam kehidupan masyarakat (sosial). Hendaknya siswa diberi kesempatan untuk berinisiatif serta diberi bimbingan atau lainnya agar lebih berhasil.

Berdasarkan identifikasa dan anlisis masalah yang menjadi fokus perbaikan, peneliti dapat merumuskan masalah apakah melalui penggunaan model pembelajaran modeling the way dapat meningkatkan hasil belajar solat pada siswa Sekolah Dasar.

Berdasarkan rumusan masalah tersebut, tujuan penelitian dalam penelitian ini adalah Proses pembelajaran dengan menggunakan model pembelajaran modeling the way untuk meningkatkan hasil belajar solat pada siswa Sekolah Dasar.

\section{METODE}

Penelitian ini merupakan penelitian kuantitatif untuk mengukur hasil belajar solat siswa. Subjek penelitian ini adalah siswa kelas II Sekolah Dasar di suatu kecamatan 
Baturetno kabupaten Wonogiri sejumlah 11 anak dengan distribusi siswa laki-laki 6 siswa dan siswa perempuan ada 5 siswa, dimana seluruh siswa kelas II ini beragama Islam. Alasan penetapan subyek penelitian ini adalah karena para siswa merupakan anak didik yang diteliti oleh guru, yang mana pada mata pelajaran Pendidikan Agama Islam materi tentang solat nilai rata - rata kelas berada di bawah KKM.

Hal ini menjadikan problem yang harus segera diatasi supaya kegiatan pembelajaran menjadi lancar dan siswa berhasil mencapai tujuan yang diharapkan. Kebanyakan dari mereka lebih suka bermain, sehingga kemandirian siswa untuk belajar dan berlatih ilmu agama masih rendah. Hal ini menimbulkan masalah bagi siswa dan guru. Akibatnya hasil belajar siswa relatif rendah. Objek penelitian adalah hasil belajar siswa tentang solat.

Penelitian dilaksanakan untuk mengetahui sejauh mana tingkat hasil belajar siswa dalam mempraktekkan solat dan mencoba mendapatkan jawaban yang akurat dengan menggunakan sejumlah instrumen. Untuk memperoleh data yang akurat pengumpulan data dilakukan dengan beberapa teknik, diantaranya dokumentasi yaitu mengumpulkan data hasil belajar solat berupa skor penilaian sebelum dan sesudah dilaksanakan model pembelajaran modeling the way pada materi solat dan foto-foto pelaksanaan kegiatan pembelajaran di kelas. Observasi dalam hal ini yaitu mengumpulkan data dengan mengamati kerjasama siswa di kelompok melalui model pembelajaran modeling the way dalam mempraktikkan solat pada setiap siklus. Tes yang berupa tes perbuatan tentang solat pada setiap siklus untuk mengetahui sejauh mana ketrampilan siswa dalam mempraktikkan solat setelah akhir pembelajaran selesai. Wawancara yang berupa daftar pertanyaan untuk menggali informasi mengenai penggunaaan model pembelajaran modeling the way.

Untuk memperoleh data diperlukan alat pengumpulan data berupa dokumen yang berupa catatan tentang hasil belajar dalam mempraktekkan solat sebelum dan sesudah dilaksanakan model pembelajaran modeling the way. Lembar observasi berupa lembar pengamatan tentang keaktifan siswa dalam pembelajaran mempraktekkan solat pada setiap siklus. Butir soal untuk tes perbuatan tentang hasil belajar solat pada setiap siklus. Butir pertanyaan untuk wawancara kepada sebagian siswa dan teman sejawat.

Kategori proses pembelajaran didasarkan dengan prosentase banyaknya siswa yang aktif mengikuti pelajaran. Target keaktifan siswa minimal mencapai $80 \%$. Kategori proses pembelajaran siswa, kurang yaitu $0-25 \%$, sedang yaitu $26 \%-49 \%$, cukup yaitu $50 \%-75 \%$, baik yaitu $76 \%$ - $100 \%$. Nilai individu siswa diperoleh dengan membandingkan skor dasar siswa (rata-rata nilai dasar sebelumnya) dengan nilai sekarang. Peningkatan hasil belajar siswa juga ditunjukkan dengan kenaikan nilai ratarata pada setiap siklus.

Target yang diharapkan dalam hasil belajar siswa tentang solat adalah dari ratarata 69,3 (kurang) pada kondisi awal, pada akhir siklus (akhir siklus II) diharapkan meningkat menjadi: Nilai hasil tes mencapai KKM 75, Rata - rata kelas dengan nilai tes 78, Target ketuntasan klasikal minimal mencapai $80 \%$.

Pada Sekolah Dasar tersebut menetapkan bahwa setiap mata pelajaran memiliki KKM yang berbeda. Penghitungan panjang interval kelas menggunakan penetapan lebih dari satu KKM. KKM mata pelajaran Pendidikan Agama Islam adalah 75, sehingga predikat nilai cukup ( C ) dimulai dari nilai 75 . Predikat di atas $C$ adalah $B$ dan A. Angka 3 diperoleh dari jumlah predikat selain D, yaitu C, B, dan A. Panjang interval kelas untuk setiap predikat adalah 8 . Sehingga rentang predikat nilai untuk mata pelajaran Pendidikan Agama Islam tersebut adalah sangat baik yaitu 93-100, baik yaitu 84-92, cukup yaitu 75-83, kurang yaitu kurang dari 75 . 
Volume 8 Nomor 1 Tahun 2020

Analisis data dalam penelitian ini, peneliti menggunakan analisis deskriptif yaitu analisis deskriptif komparatif dengan membandingkan nilai tes antar siklus dan indikator kinerja. Analisis data dilakukan dengan metode deskriptif prosentase. Data hasil observasi dianalisis dengan analisis deskriptif kualitatif berdasarkan hasil pengamatan dan refleksi tiap siklus. Diharapkan dengan menggunakan model pembelajaran modeling the way, terjadi peningkatan hasil belajar solat pada siswa.

\section{HASIL DAN PEMBAHASAN}

\section{Hasil Penelitian Kondisi Awal}

Berdasarkan proses pembelajaran kondisi awal, masih banyak siswa yang ramai, ada pula yang terlihat diam, pembelajaran dianggap kurang menarik. Siswa yang aktif mengikuti proses pembelajaran sebanyak 3 siswa, apabila diprosentasekan sebesar 27,3 \% masuk kategori kurang. Siswa yang terlihat kurang aktif sebanyak 8 siswa dengan prosentase sebesar $72,7 \%$. Berikut tabel distribusi keaktifan siswa selama kondisi awal.

\section{Tabel 1}

Distribusi Keaktifan Siswa dalam Proses Pembelajaran Kondisi awal

\begin{tabular}{|c|c|c|c|}
\hline No & Indikator Keaktifan & Frekuensi & Prosentase \\
\hline 1 & Aktif & 3 & $27,3 \%$ \\
\hline 2 & Kurang Aktif & 8 & $72,7 \%$ \\
\hline
\end{tabular}

Berdasarkan tabel distribusi keaktifan siswa dalam proses pembelajaran kondisi awal, didapatkan hasil dari 11 siswa, keaktifan siswa dalam proses pembalajaran mencapai $27,3 \%$ masukm kategori kurang. Rendahnya keaktifan siswa dalam proses pembelajaran mata pelajaran Pendidikan Agama Islam pada materi mempraktikkan solat dengan tertib berkaitan dengan hasil belajar siswa yang dicapai siswa. Hasil belajar tugas harian dan tugas rumah akan berdampak pada hasil belajar ulangan harian.

Didapatkan hasil belajar belum semua siswa mencapai ketuntasan minimal. Berdasarkan hasil tes ternyata nilai rata-rata kelas 69,3. Siswa yang mencapai mencapai tingkat ketuntasan minimal ada 4 siswa, sedangkan 7 siswa belum mencapai tingkat ketuntasan minimal. Data ini menunjukkan hasil belajar yang rendah karena yang melebihi target nilai KKM 75 sebesar 36,4 \% dari jumlah siswa. Dokumen evaluasi kondisi awal dapat dilihat pada tabel distribusi di bawah ini.

\section{Tabel 2}

Daftar Distribusi Nilai Kondisi awal

\begin{tabular}{|c|c|c|c|l|}
\hline No & Nilai Interval & Frekuensi & Prosentase & Predikat \\
\hline 1. & $93-100$ & 0 & $0 \%$ & $\begin{array}{l}\text { Sangat } \\
\text { Baik }\end{array}$ \\
\hline 2. & $84-92$ & 0 & $0 \%$ & Baik \\
\hline 3. & $75-83$ & 4 & $36,4 \%$ & Cukup \\
\hline 4. & $\mathrm{D}<75$ & 7 & $63,6 \%$ & Kurang \\
\hline \multicolumn{2}{|r|}{ Siswa Tuntas } & 11 & $100 \%$ & \\
\cline { 1 - 3 } Siswa Belum Tuntas & 4 & $36,4 \%$ & \\
\hline
\end{tabular}


Dari tabel di atas hasil tes menunjukkan terdapat 0 siswa yang mendapatkan nilai dalam interval 93-100 dengan prosentase $0 \%$. Terdapat 0 siswa yang mendapatkan nilai pada interval 84-92 dengan prosentase 0\%. Siswa yang mendapatkan nilai pada interval 75-83 yaitu tuntas sebanyak 4 siswa dengan prosentase $36,4 \%$. Sedangkan pada interval $<75$ terdapat 7 siswa dengan prosentase $63,6 \%$ termasuk kategori belum tuntas. Lebih jelas ditunjukan dalam grafik berikut ini :

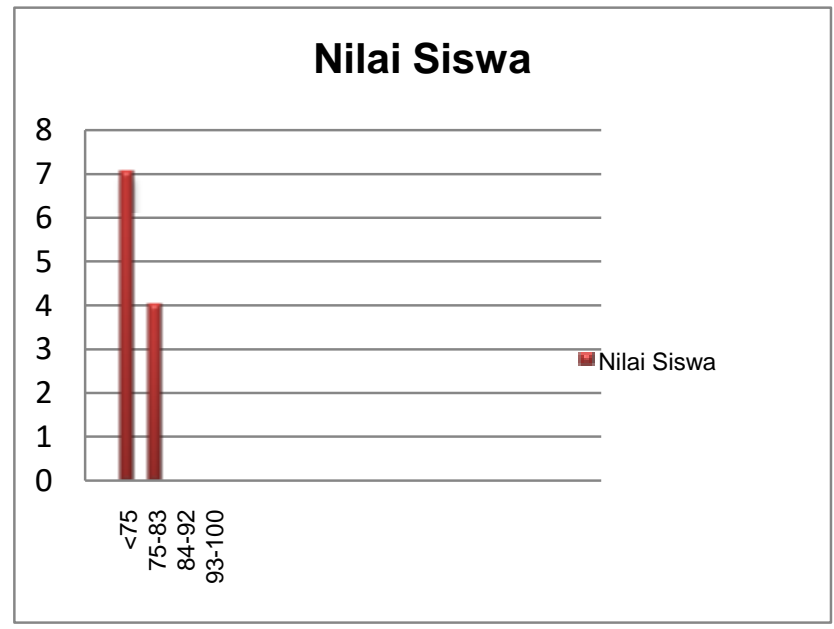

\section{Grafik 1. \\ Jumlah siswa dan nilai siswa pada kondisi awal}

Hasil pengamatan terhadap proses pembelajaran pada Siklus I sudah menunjukkan adanya peningkatan dibandingkan pada kondisi awal. Siswa yang tidak aktif, kurang meperhatikan pelajaran sudah berkurang, siswa yang pasif/diam saja sudah tidak terlihat. Kebanyakan dari mereka sudah berpartisipasi aktif. Siswa yang aktif mengikuti pembelajaran sebanyak 6 siswa dengan prosentase 54,5\% termasuk kategori cukup. Sedangkan siswa yang kurang aktif sebanyak 5 siswa dengan prosentase $45,5 \%$. Berikut ini tabel distribusi proses pembelajaran Siklus I.

Tabel 3

Distribusi Keaktifan Siswa dalam Proses Pembelajaran Siklus I

\begin{tabular}{|c|c|c|c|}
\hline No & $\begin{array}{c}\text { Indikator } \\
\text { Keaktifan }\end{array}$ & Frekuensi & Prosentase \\
\hline 1 & Aktif & 6 & $54,5 \%$ \\
\hline 2 & Kurang Aktif & 5 & $45,5 \%$ \\
\hline
\end{tabular}

Peningkatan keaktifan siswa tentu saja mempengaruhi semangat mereka untuk belajar. Semangat yang ditimbulkan akan membantu mereka memahami materi yang sebelumnya dirasa masih susah dihafal atau diingat gerakannya namun menjadi mudah sehingga ketekunan dalam belajar membuahkan hasil pada hasil belajar mereka. Pada awal pelaksanaan tes siswa terlihat antusias dalam mengerjakan soal, namun selang beberapa lama masih terlihat diantara mereka ada yang mencoba untuk bertanya pada teman yang lain. Sebagian dari mereka terlihat sangat percaya diri dalam mengerjakan soal, sebagian lagi masih nampak kebingungan. Pelaksanaan tes berlangsung tanpa kendala yang berarti. Guru mengingatkan untuk menjaga ketenangan dan kedisiplinan selama pelaksanaan tes. Siswa yang kebingungan tetap 
berusaha mengerjakan tes sebisa mereka. Data hasil belajar Siklus I ditampilkan dalam tabel distribusi di bawah ini:

Tabel 4

Daftar Distribusi Nilai Siklus I

\begin{tabular}{|c|c|c|c|c|}
\hline No & $\begin{array}{c}\text { Nilai } \\
\text { Interval }\end{array}$ & Frekuensi & Prosentase & Predikat \\
\hline 1. & $93-100$ & 0 & $0 \%$ & Sangat baik \\
\hline 2. & $84-92$ & 2 & $18,2 \%$ & Baik \\
\hline 3. & $75-83$ & 5 & $45,4 \%$ & Cukup \\
\hline 4. & $\mathrm{D}<75$ & 4 & $36,4 \%$ & Kurang \\
\hline \multicolumn{2}{|c|}{$\sum f$} & 11 & $100 \%$ & \\
\hline \multicolumn{2}{|c|}{ Siswa Tuntas } & 7 & $63,6 \%$ & \\
\hline \multicolumn{2}{|c|}{$\begin{array}{c}\text { Siswa Belum } \\
\text { Tuntas }\end{array}$} & 4 & $36,4 \%$ & \\
\hline
\end{tabular}

Dari tabel di atas hasil tes menunjukkan bahwa tidak ada siswa yang mendapatkan nilai pada interval 93-100 dengan prosentase $0 \%$. Terdapat 2 siswa yang mendapatkan nilai pada interval 84-92 dengan prosentase $18,2 \%$. Terdapat 5 siswa yang mendapatkan nilai pada interval 75-83 dengan prosentase $45,4 \%$. Sedangkan pada interval $<75$ terdapat 4 siswa dengan prosentase $36,4 \%$ termasuk kategori belum tuntas. Berdasarkan data tersebut, siswa yang berhasil melampaui nilai KKM ada 7 siswa. Rata - rata pada Siklus I adalah 76 dengan presentase ketuntasan $63,6 \%$. Lebih jelas ditunjukan dalam grafik berikut ini :

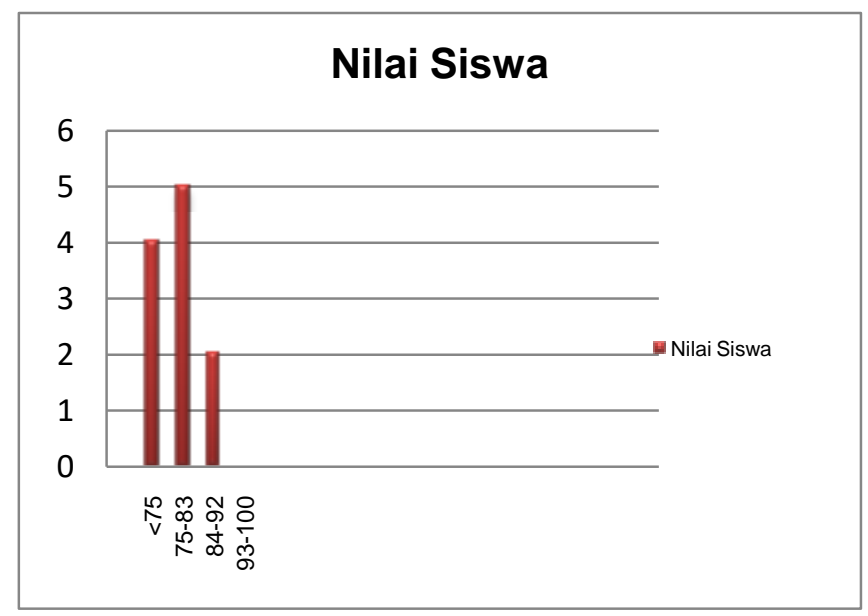

\section{Grafik 2.}

Jumlah siswa dan nilai siswa pada Siklus I

\section{Hasil Penelitian Siklus II}

Hasil pengamatan proses pembelajaran pada Siklus II sudah menunjukkan keberhasilan yang maksimal terbukti tidak ada siswa yang belum tuntas, nilai rata-rata kelas mencapai 88 dengan predikat baik, otomatis mencapai ketuntasan belajar $100 \%$. Siswa yang tidak aktif, kurang meperhatikan pelajaran sudah tidak ada, siswa yang pasif/diam saja sudah tidak terlihat. Hampir semua siswa sudah berpartisipasi aktif. Siswa yang aktif mengikuti pembelajaran sebanyak 11 siswa dengan prosentase 100 
\% termasuk kategori baik. Sedangkan siswa yang kurang aktif sudah tidak ada. Berikut ini tabel distribusi proses pembelajaran Siklus II.

\section{Tabel 5}

Distribusi Keaktifan Siswa dalam Proses Pembelajaran Siklus II

\begin{tabular}{|c|c|c|c|}
\hline No & $\begin{array}{c}\text { Indikator } \\
\text { Keaktifan }\end{array}$ & Frekuensi & Prosentase \\
\hline 1 & Aktif & 11 & $100 \%$ \\
\hline 2 & Kurang Aktif & 0 & $0 \%$ \\
\hline
\end{tabular}

Peningkatan keaktifan siswa tentu saja mempengaruhi semangat mereka untuk belajar. Semangat yang ditimbulkan akan membantu mereka memahami materi yang sebelumnya dirasa masih susah dihafal atau diingat gerakannya namun menjadi mudah sehingga ketekunan dalam belajar membuahkan hasil pada hasil belajar mereka. Pada pelaksanaan tes siswa terlihat antusias dalam mengerjakan soal, sudah tidak ada lagi siswa yang terlihat diantara mereka ada yang mencoba untuk bertanya pada teman yang lain. Sebagian besar mereka terlihat sangat percaya diri dalam mengerjakan soal, sudah tidak ada lagi yang nampak kebingungan. Pelaksanaan tes berlangsung tanpa kendala yang berarti. Guru mengingatkan untuk menjaga ketenangan dan kedisiplinan selama pelaksanaan tes. Semua siswa dengan percaya diri berusaha mengerjakan tes semaksimal mungkin. Data hasil belajar Siklus II ditampilkan dalam tabel distribusi di bawah ini:

\section{Tabel 6}

Daftar Distribusi Nilai Siklus II

\begin{tabular}{|c|c|c|c|c|}
\hline No & $\begin{array}{c}\text { Nilai } \\
\text { Interval }\end{array}$ & Frekuensi & Prosentase & Predikat \\
\hline 1. & $93-100$ & 2 & $18,2 \%$ & Sangat baik \\
\hline 2. & $84-92$ & 3 & $27,3 \%$ & Baik \\
\hline 3. & $75-83$ & 6 & $54,5 \%$ & Cukup \\
\hline 4. & $D<75$ & 0 & $0 \%$ & Kurang \\
\hline \multicolumn{2}{|r|}{$\sum f$} & 11 & $100 \%$ & \\
\hline \multicolumn{2}{|c|}{ Siswa Tuntas } & 11 & $100 \%$ & \\
\hline \multicolumn{2}{|c|}{$\begin{array}{c}\text { Siswa Belum } \\
\text { Tuntas }\end{array}$} & 0 & $0 \%$ & \\
\hline
\end{tabular}

Dari tabel di atas hasil tes menunjukkan bahwa terdapat 2 siswa yang mendapatkan nilai pada interval 93-100 dengan prosentase 18,2\%. Terdapat 3 siswa yang mendapatkan nilai pada interval $84-92$ dengan prosentase $27,3 \%$. Sedangkan pada interval 75-83 terdapat 6 siswa dengan prosentase $54,5 \%$ termasuk kategori cukup. Berdasarkan data tersebut, siswa yang berhasil melampaui nilai KKM ada 11 siswa. Rata-rata nilai hasil belajar pada Siklus II adalah 85 dengan presentase ketuntasan $100 \%$. Lebih jelas ditunjukan dalam grafik berikut ini : 


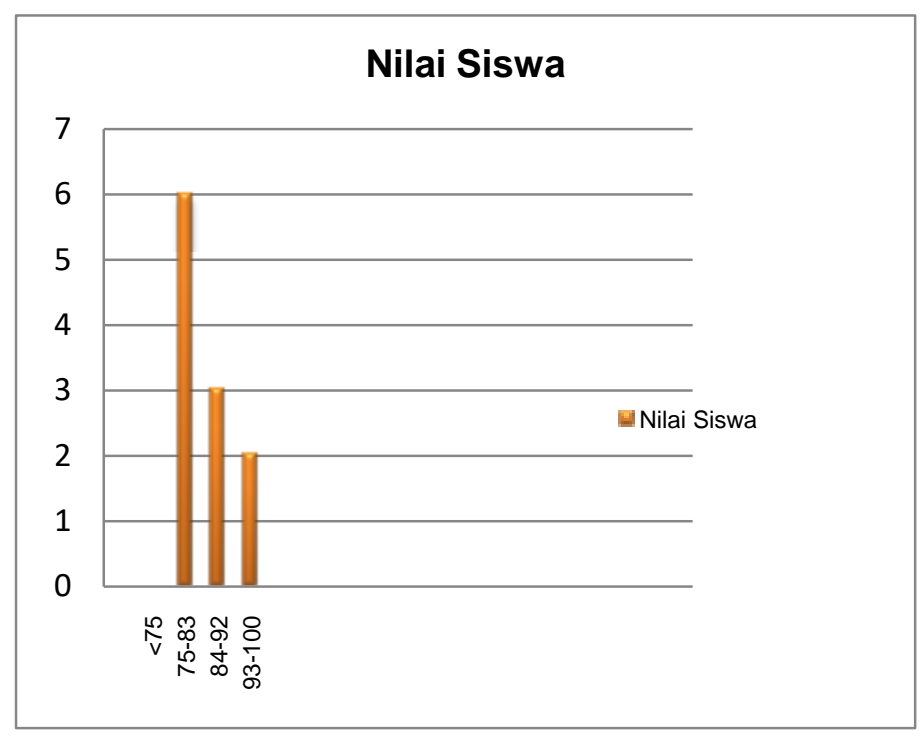

Grafik 3.

\section{Jumlah siswa dan nilai siswa pada Siklus II}

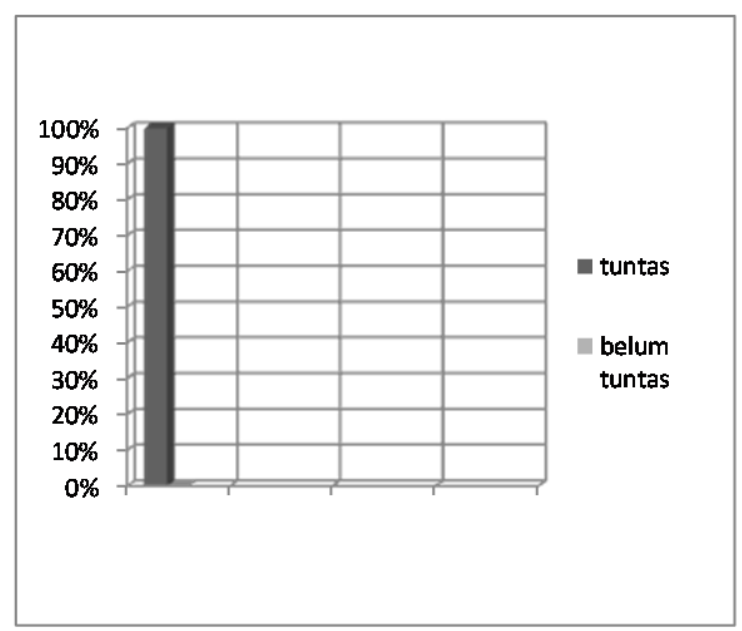

\section{Grafik 4. \\ Ketuntasan siswa pada kondisi Siklus II}

Berdasarkan hasil observasi proses pembelajaran pada Kondisi awal, Siklus I dan Siklus II siswa yang aktif sebesar $27,3 \%$ pada kondisi awal, kemudian meningkat menjadi $54,5 \%$ pada Siklus I dan menjadi $100 \%$ pada pembelajaran Siklus II. Pembahasan hasil penelitian pada penelitian ini fokus pada dua variabel yaitu keaktifan belajar dan hasil belajar siswa. Nilai hasil belajar yang diperoleh dari hasil tes dari kondisi kondisi awal ke Siklus I kemudian ke Siklus II mengalami kenaikan yaitu dari rata-rata pada kondisi kondisi awal naik menjadi rata-rata di Siklus I kemudian naik menjadi rata-rata di Siklus II. Peningkatan ketuntasan siswa juga terjadi kenaikan dari 4 siswa atau $36,4 \%$ pada kondisi awal menjadi 7 siswa atau 63,6\% pada Siklus I dan menjadi 11 siswa atau $100 \%$ siswa tuntas pada Siklus II. 
Ada beberapa penelitian terdahulu yang relevan dengan penelitian ini, antara lain: 1) Penelitian Musyawwarotul IImiyah dengan judul "Penerapan Metode Modeling The Way Untuk Meningkatkan Hasil Belajar Fiqih Materi Tata Cara Sholat Berjamaah Siswa Kelas II MI Ma'arif At-Taqwa Lamongan", ternyata dengan penelitian tersebut dapat meningkatkan hasil belajar. Jenis Penelitian ini adalah penelitian tindakan kelas (PTK) dengan menggunakan metode Modelling The Way. Subjek dan tempat penelitian ini adalah siswa kelas II MI Ma'arif At-Taqwa Lamongan yang berjumlah 31 siswa. 2) Penelitian Siti Mufadlilah dengan judul "Upaya Meningkatkan Hasil Belajar Siswa Menggunakan Strategi Modeling The Way Pada Pembelajaran Fiqih Materi Adzan dan Iqamah di Kelas II MI Tarbiyahtul Islam Genuk Semarang Semester II Tahun Pelajaran 2015/2016." Dalam penelitian tersebut juga dapat meningkatkan hasil belajar siswa. Penelitian ini dilatarbelakangi kriteria Ketuntasan Minimum (KKM) pada tes praktek adzan dan iqamah dari 34 siswa hanya $47.1 \%$ dari jumlah siswa yaitu 16 siswa. 3) Penelitian Elmiati dengan judul "Penerapan Strategi Modelling The Way Untuk Meningkatkan Kemampuan Melafazkan Hukum Qawli Shalat fardhu Siswa SMP Rusqah Pekanbaru." Dalam penelitian tersebut juga dapat meningkatkan hasil belajar siswa.

Berdasarkan penelitian-penelitian tersebut, maka dapat disimpulkan bahwa perbedaan dan persamaan dari penelitian yang telah dilakukan dengan penelitian yang dilakukan peneliti adalah 1) Penelitian Musyawwarotul IImiyah dengan judul "Penerapan Metode Modeling The Way Untuk Meningkatkan Hasil Belajar Fiqih Materi Tata Cara Sholat Berjamaah Siswa Kelas II MI Ma'arif At-Taqwa Lamongan". Penelitian ini dengan penelitian yang akan dilakukan perbedaannya pada materinya yaitu materi sholat, sedang materi pada penelitian yang akan dilakukan materi solat. Sedangkan persamaannya yaitu pada penggunaan model pembelajaran modeling the way dan upaya yang ditingkatkan sama yaitu hasil belajar, juga siswa yang diteliti sama yaitu kelas II SD/MI. Selain itu materinya memang berbeda tetapi sama-sama materi yang memerlukan praktek langsung yaitu materi sholat memerlukan praktek langsung sedang materi solat juga memerlukan praktek langsung. 2) Penelitian Siti Mufadlilah dengan judul "Upaya Meningkatkan Hasil Belajar Siswa Menggunakan Strategi Modeling The Way Pada Pembelajaran Fiqih Materi Adzan dan lqamah di Kelas II MI Tarbiyahtul Islam Genuk Semarang Semester II Tahun Pelajaran 2015/2016". Penelitian ini dengan penelitian yang akan dilakukan perbedaannya pada materinya yaitu materi adzan dan iqamah, sedang materi pada penelitian yang akan dilakukan materi solat. Sedangkan persamaannya yaitu pada penggunaan model pembelajaran modeling the way dan upaya yang ditingkatkan sama yaitu hasil belajar, juga siswa yang diteliti sama yaitu kelas II SD/MI. Selain itu materinya memang berbeda tetapi sama-sama materi yang memerlukan praktek langsung, yaitu materi azan dan iqamah memerlukan praktek langsung sedang materi solat juga memerlukan praktek langsung. 3) Penelitian Elmiati dengan judul "Penerapan Strategi Modelling The Way Untuk Meningkatkan Kemampuan Melafazkan Hukum Qawli Shalat fardhu Siswa SMP Rusqah Pekanbaru". Penelitian ini dengan penelitian yang akan dilakukan perbedaannya pada upaya yang ditingkatkan yaitu kemampuan melafazkan hukum qawli shalat sedang penelitian yang akan dilakukan upaya yang ditingkatkan adalah hasil belajar solat. Selain itu siswa yang diteliti juga berbeda yaitu siswa SMP, sedang pada penelitian yang akan dilakukan siswa kelas II SD. Sedangkan persamaannya pada penggunaan model pembelajaran modeling the way.

Berdasarkan beberapa penelitian tersebut diatas dapat disimpulkan bahwa penggunaan model pembelajaran modeling the way dapat meningkatkan hasil belajar siswa. Harapan yang ingin dicapai oleh peneliti dalam penggunaan model pembelajaran modeling the way ini adalah untuk meningkatkan hasil belajar solat pada siswa sehingga tujuan dalam pembelajaran dapat tercapai. 


\section{SIMPULAN}

Berdasarkan hasil penelitian, maka dapat disimpulkan bahwa terdapat peningkatan hasil belajar solat setelah diberikan pembelajaran dengan model pembelajaran modeling the way pada siswa kelas II Sekolah Dasar di suatu sekolah di kecamatan Baturetno Wonogiri yaitu nilai hasil belajar dengan ketentuan KKM 75 diperoleh hasil tes dari kondisi prasiklus ke Siklus I kemudian ke Siklus II mengalami kenaikan yaitu dari rata-rata kelas nilai hasil belajar 67 dengan predikat nilai kurang pada kondisi prasiklus naik menjadi rata-rata 76 dengan predikat nilai cukup di Siklus I kemudian naik menjadi rata-rata 85 dengan predikat nilai baik di Siklus II. Peningkatan ketuntasan siswa dengan jumlah siswa 11, juga terjadi kenaikan dari 4 siswa atau $36,4 \%$ pada kondisi awal menjadi 7 siswa atau 63,6\% pada Siklus I dan menjadi 11 siswa atau $100 \%$ siswa tuntas pada Siklus II. Pembelajaran dengan menggunakan model pembelajaran Modeling The Way juga berdampak positif terhadap kinerja guru untuk selalu memberikan persiapan dan pelayanan yang terbaik dalam pembelajaran di kelas sehingga guru dituntut untuk selalu berkreasi menciptakan dan menerapkan model-model pembelajaran yang disenangi oleh siswa, membangkitkan keaktifan siswa, membangkitkan rasa ingin tahu, memudahkan dalam mentransformasikan kompetensi materi pelajaran sehingga siswa lebih mudah memahami kompetensi pelajaran yang disampaikan oleh guru.

\section{DAFTAR PUSTAKA}

Abdurrahman, Mulyono. 1999. Pendidikan Bagi Anak Berkesulitan, Rineka Cipta.

Arends dalam Suyitno. 2011. Pemilihan Model-model Pembelajaran dan Penerapannya di Sekolah, Semarang: Universitas Negeri Semarang.

Arikunto, Suharsimi. 2009. Prosedur Penelitian, Jakarta: Rineka Cipta.

Departemen Pendidikan Nasional. 2007. Kamus Besar Bahasa Indonesia, Jakarta: Balai Pustaka.

Dimyati dan Mudjiono. 2008. Belajar dan Pembelajaran, Jakarta: Rineka Cipta.

Gagne dalam Dimyati, Mudjiono. 2008. Belajar dan Pembelajaran, Jakarta: Rineka Cipta.

Hamalik, Oemar. 2008. Psikologi Belajar Mengajar, Jakarta: PT. Rineka Cipta.

Hasan, Chalijah. 1994. Dimensi-dimensi Psikologi Pendidikan, Surabaya: Al-lkhlas. https://jagad.id/wp.content/uploads/2014/02/Gerakan dan bacaan solat, diakses tgl. 16 Maret 2019 pukul 16.28

Imam, Khsnul, dkk. 2011. Belajar Mengamalkan Agama Islam Pendidikan Agama Islam untuk Sd, Jakarta: Pusat Kurikulum dan Perbukuan Kementerian Pendidikan Nasional.

Istarani. 2009. 58 Model Pembelajaran Inovatif, Medan: Media Persada, 2011 
Kingsley, Howard dalam Sudjana, Penelitian dan Penilaian Pendidikan, Bandung: Sinar Baru Algesindo.

Pujosuwarno, Sayekti. 1995. Penulisan Usulan dan Laporan penelitian Kualitatif, Yogyakarta: Lemlit IKIP Yogyakarta.

Purwanto, Ngalim. 2007. Psikologi Pendidikan, Bandung: Remaja Rosda Karya.

Sabri, M. Alisuf. 2010. Psikologi Pendidikan, Jakarta: Pedoman Ilmu Jaya.

Sanjaya. 2009. Strategi Pembelajaran Berorientasi Standart Proses Pendidikan, Jakarta: Prenada Media Group.

Sriyono, dkk. 1992. Tehnik Belajar Mengajar Dalam CBSA, Jakarta: Rineka Cipta.

Slameto. 2008. Belajar dan Faktor-faktor Yang Mempengaruhinya, Jakarta: Rineka Cipta.

Sudjana, Nana, dan Rivai, Ahmad. 2001. Media Pengajaran, Bandung: Sinar Baru.

Syah, Muhibbin. 2011. Psikologi Belajar, Jakarta: Bumi Aksara.

Tri Anni, Catharina. 2004. Psikologi Belajar, Semarang: IKIP Semarang Press.

Usman, Husaini dan Setiady Akbar, Purnomo. 2008. Metodologi Penelitian Sosial, Jakarta: Bumi Aksara.

Zain, Djamarah. 2006. Strategi Belajar Mengajar, Jakarta: Rineka Cipta.

Zaini, Hisyam, Munthe, Bermawy, Ayu Aryani, Sekar. 2008. Strategi Pembelajaran Aktif, Yogyakarta: Pustaka Insan Madani. 